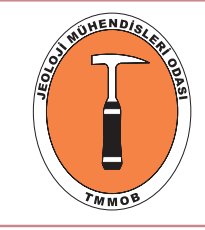

\author{
Türkiye Jeoloji Bülteni \\ Geological Bulletin of Turkey \\ 64 (2021) 253-266 \\ doi:10.25288/tjb.927117
}

\title{
Holocene Palynology and Pollen-Based Palaeoclimate Reconstruction of Lake Erçek (Eastern Anatolia); Short-Term Climatic Fluctuations and their Relation with Global Palaeoclimatic Change; Results of Cores E1 and E10 \\ Erçek Gölü'nün Holosen Palinolojisi ve Polene Dayalı Paleoiklim Yapılandırması \\ (Doğu Anadolu, Türkiye); Kısa Dönem İklim Salınımları ve \\ Global Paleoiklim Değişimleri ile İlişkisi; E1 ve E10 Karotlarının Sonuçları
}

\begin{abstract}
Güldem Kamar ${ }^{\mathbb{D}}$
Van Yüzüncü Yıl Üniversitesi, Mühendislik Fakültesi, Jeoloji Mühendisliği Bölümü, 65080, Tuşba, Van, Türkiye

\begin{tabular}{ccc}
\hline - Geliş/Received: 24.04 .2021 & •Düzeltilmiş Metin Geliş/Revised Manuscript Received: 04.07.2021 & • Kabul/Accepted: 05.07 .2021
\end{tabular}

Research Article/Araștırma Makalesi Türkiye Jeol. Bül. / Geol. Bull. Turkey
\end{abstract}

\begin{abstract}
This study is a palynological and stratigraphical investigation of E1 and E10 core samples from the southern part of Lake Erçek (Eastern Anatolia, Turkey). Core samples were taken by a gravity corer from different water depths. Deposits in the core samples include mostly laminated rhythmic sediments, massive and graded layers and a tephra layer from E10 core, representing different time spans because of the faulted ground of the lake. Tentative time scales of the core samples are based on pollen and tephra correlation with Lake Van deposits. According to the palynological investigations, palaeovegetation of Greenlandian is represented by Amaranthaceaedominant halophytic vegetation and semi-arid palaeoclimate conditions based on pollen analysis around Lake Erçek. The Meghalayan stage is mainly characterized by Poaceae-dominated steppe vegetation and increasing human impact according to anthropogenic pollen indicators. The Meghalayan palaeoclimate of Lake Erçek was more humid than Greenlandian and is represented by maximum deciduous Quercus expansion in recent times around the Lake Erçek area.
\end{abstract}

Keywords: Greenlandian, Holocene, Lake Erçek, Meghalayan, palaeoclimate, palynology.

Öz: Bu çalışma Erçek Gölü'nün (Doğu Anadolu, Türkiye) güney kesiminden alınan E1ve E10 sediment karotlarının palinolojik ve stratigrafik incelenmesini kapsamaktadır. Karot örnekleri farklı su derinliklerinden gravite karot örnekleyici kullanılarak alınmıştır. Karot örneklerinin litolojisi çoğunlukla laminalı ritmik sediman, masif ve tabakalı seviyeler ile E10 karotunda bulunan tefra seviyesi içermekte ve göl tabanının fayl oluşundan dolayı farkl zaman aralıkların temsil etmektedir. Karot örneklerinin yaşlandırılması Van Gölü örneklerinin polen ve tefra seviyeleriyle korelasyonuna dayandırllarak belirlenmiştir. Palinolojik inceleme sonuçlarına göre, Erçek Gölü’nün, Grönlandiyen paleovejetasyonu Amaranthaceae familyası baskın halofitik vejetasyon ve yarı kurak paleoiklim koşulları ile temsil edilmektedir. Meghaliyen katı ise Poaceae familyası baskın step vejetasyonu ve antropojenik pollenlere göre artan insan etkisi ile karakterize edilmektedir. Erçek Gölü çevresinde Meghaliyen paleoiklimi Grönlandiyen'den daha nemlidir ve günümüze doğru gelindikçe maksimum yaprak döken Quercus yayllımı ile temsil edilmektedir.

Anahtar Kelimeler: Erçek Gölü, Grönlandiyen, Holosen, Meghaliyen, paleoiklim, palinoloji. 


\section{INTRODUCTION}

Lake deposits act as a palaeoclimate archive with well-preserved deposits rich in palynomorphs. Holocene sediment deposits such as in small lakes suggest short-term climatic fluctuations from local to regional and global. These closed and small sediment basins like Lake Erçek have stored climatic records and lake level fluctuations on a time scale varying from thousands of years to tens of years. Investigations of $\sim 50$ globallydistributed palaeoclimate records show six periods of significant rapid climatic change during the periods $9000-8000,6000-5000,4200-3800$, $3500-2500,1200-1000$, and $600-150 \mathrm{cal}$ yr BP. These are characterized by polar cooling, tropical aridity, and major atmospheric circulation changes (Mayewski et al., 2004) including two main dry phases during Holocene.

Climate variability during Holocene has been recorded in Anatolia and also closer locations to Lake Erçek such as Lake Sevan (Armenia) and Lake Urmia (Iran) (Ülgen et al., 2012; Eriş, 2013; Ocakoğlu et al., 2013; Çağatay et al., 2014; Dean et al., 2015; Talebi et al., 2016; Ön et al., 2017; Hayrapetyan et al., 2018; Ön \& Özeren, 2018). In northwest Anatolia, positive shifts in $\delta^{18} \mathrm{O}$ of early Holocene indicate a mean summer temperature rise and increased aridity (Ocakoğlu et al., 2013). Deposits in Lake İznik points to arid periods and a lowered lake level for late Holocene at 4.2 and 3 ka BP (Ülgen et al., 2012). The Medieval Climatic Anomaly and more humid conditions around 1110 BP then drought and humid periods after this period have been defined respectively in northeastern Anatolia (K1lıç et al., 2018). In Eastern Anatolia, multiproxy data results from Lake Hazar indicate warm and humid climate conditions at the onset of Holocene (Biltekin et al., 2018) and a dropping water level about $3 \mathrm{ka}$ BP due to cold and dry conditions (Eriş, 2013). Palaeoclimate changes of the Quaternary period in Lake Van have been investigated in detail (van Zeist \& Woldring, 1978; Wick et al., 2003; Litt et al., 2009; Kaplan \& Örçen, 2011; Kaplan, 2013a; Kaplan, 2013b; Litt et al., 2014; Pickarski et al., 2015; Kamar, 2018). The $600 \mathrm{ka}$ BP pollen record of Lake Van covers several glacial and interglacial periods (Litt et al., 2014). Almost all the palynological and palaeoclimatic data based on pollen analysis in Eastern Anatolia have been mainly focused on the Lake Van deposit. There are several smaller and high altitude lakes located on Eastern Anatolia Plateau and Lake Erçek is one of them. This study aims to investigate the palynology and carry out a pollen-based palaeoclimate reconstruction of Holocene deposits in Lake Erçek to identify shortterm palaeoclimate and palaeoflora changes.

\section{STUDY SITE}

Lake Erçek is a soda lake and is located in Eastern Anatolia east of Lake Van at about $1815 \mathrm{~m}$ above sea level with a surface area of $92 \mathrm{~m}^{2}$ and water depth of $40 \mathrm{~m}$ (İpek \& Sar1, 1998). Several geological units ranging from pre-Cenozoic to Quaternary occur around Lake Erçek, which is situated at the intersection of the Afro/Arabian Plate to the south and the Eurasian Plate to the north and east (Figure 1). The continental collision between these two plates along the Bitlis-Zagros Suture Zone $(\sim 13 \mathrm{Ma})$ gave rise to the crustal shortening and uplift of the East Anatolian region (Şengör \& Yılmaz, 1981; Şaroğlu \& Y1lmaz, 1986; Yılmaz et al., 1987; Koçyiğit et al., 2001). Gürpınar, Everek and Alaköy faults are the main faults that have been formed, and they control the eastern part of the Lake Van basin as a result of the collision (Okuldaş \& Üner, 2013; Sağlam Selçuk, 2016). 


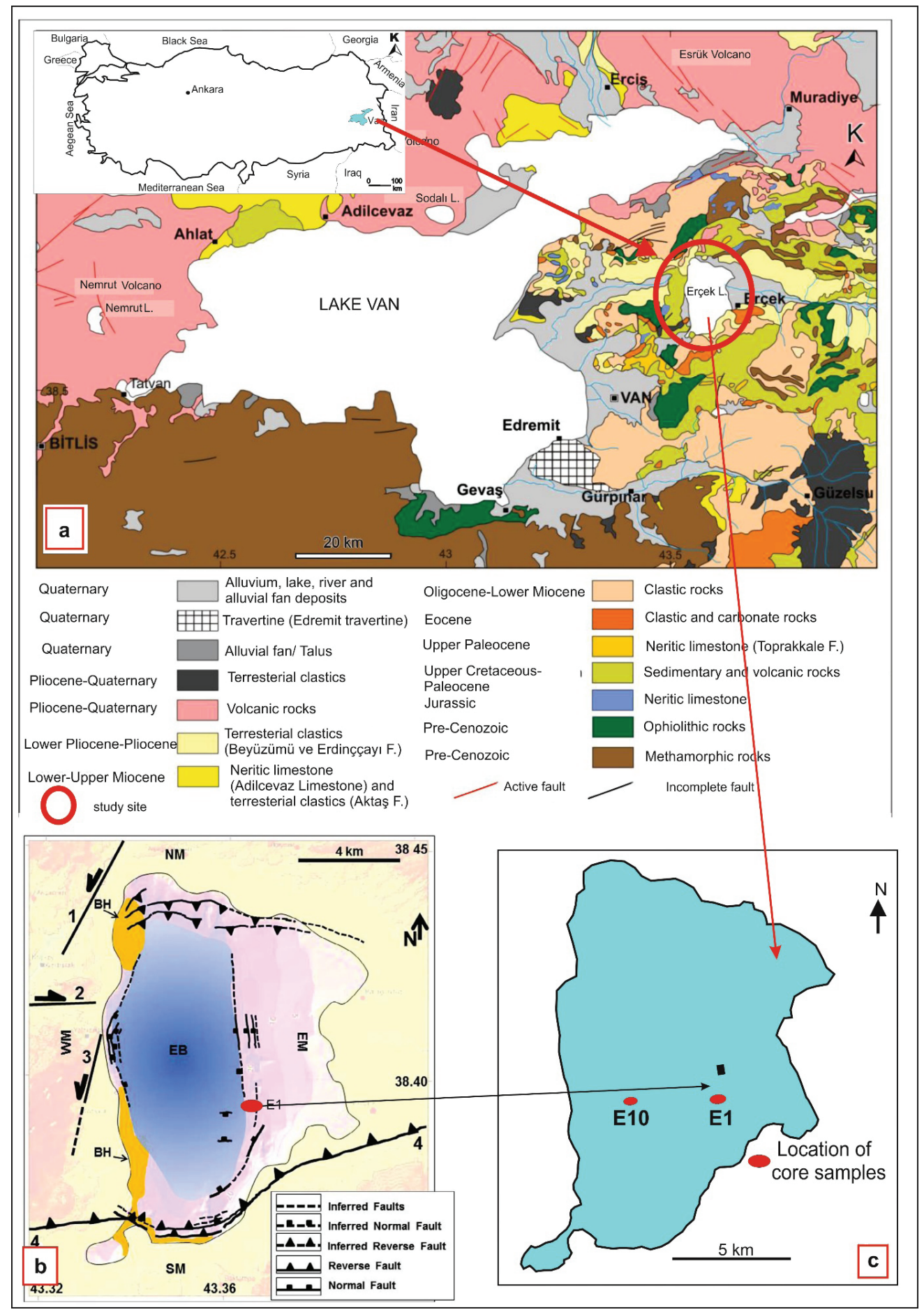

Figure 1. a) Location and geology map of surroundings of Lake Erçek (geological map taken from Alan et al., 2011), b) Detailed deformational elements and main faulting patterns of Lake Erçek (taken from Toker et al., 2017), c) Locations of E1 and E10 core samples.

Şekil 1. a)Erçek Gölü'nün lokasyonu ve çevresinin jeoloji haritası (jeoloji haritası Alan ve diğ., 2011'den alınmıştır), b) Erçek Gölü'nün ana fay sistemleri ve detaylı deformasyonal elemanları (Toker ve diğ., 2017'den alınmıştır), c) E1 ve E10 karot örneklerin lokasyonlarl. 
The bathymetry and seismic features of Lake Erçek have been published (İpek \& Sar1, 1998; Toker et al., 2017; Toker \& Tur, 2018). Reverse normal and inferred normal fault systems have been identified at the bottom of Lake Erçek (Figure 1) (Toker et al., 2017; Toker \& Tur, 2018).

The surroundings of Lake Erçek are covered by eastern Anatolian lowland steppe and the southern part of the lake is dominated by Eastern Anatolia high mountain steppe (Figure 2) (Eken et al., 2006). Limonium meyeri, Tamarix parviflora, Carex divisia, Typha latifolia, Salix alba, Hippophae rhamnoides, Plantago lanceolata, Prunella vulgaris, Polygonum bistorta, Ephedra distachia, and Ephedra major plants comprise the lowland steppe vegetation of Eastern Anatolia. Plants such as Acantholimon kotschyi, Artemisia tauriaca, Centaurea virgata, etc. have been observed in the high mountain steppe up to 2600-2700 m. Rumex scutatus and Centranthus longiflorus assemblages widely cover the valley borders up to 1300-2200 m (Tatl1, 2004).

The lowest mean annual temperature is 3.7 ${ }^{\circ} \mathrm{C}$ and the highest mean annual temperature is $14.9{ }^{\circ} \mathrm{C}$ for the Van region, according to the last eighty years climate data of the Turkish State Meteorological Service (https://www.mgm. gov.tr/veridegerlendirme/il-ve-ilceler-istatistik. aspx $? \mathrm{k}=\mathrm{A} \& \mathrm{~m}=\mathrm{VAN})$. In accordance with the Thornthwaite method, semi-dry and semi-humid climatic conditions prevail in Van province (Şensoy, et al., 2021).

\section{MATERIAL AND METHODS}

Core samples were collected in 2014 with a gravity corer from different water depths from $9 \mathrm{~m}$ to $39 \mathrm{~m}$ (Figure 1). The stratigraphical and palynological aspects of two core samples, E1 and E10, are investigated in this study. With a length of $111 \mathrm{~cm}$, the E1 core was taken from a water depth of 18 $\mathrm{m}$ at an altitude of $1826( \pm 5) \mathrm{m}$ above sea level. The $140 \mathrm{~cm}$ long sample E10 was taken from a depth of $36 \mathrm{~m}$ at an altitude of $1815( \pm 5) \mathrm{m}$ above sea level (Figure 1). Samples were taken from 3-5 $\mathrm{cm}$ intervals for palynological investigation and prepared according to the standard palynological sample preparation method, treated with $\mathrm{HCl}$, $\mathrm{HF}$ and $\mathrm{ZnCl}_{2}$ (Ediger, 1986). A minimum of 450 pollen grains were counted per sample. The pollen descriptions, plates and illustrations of Wodehouse (1935), Erdtman (1943), Faegri \& Iversen (1989), Moore et al. (1991) and Beug (2004) were used for pollen identification. Pollen diagrams were plotted using Tilia computer program (E. C. Grimm, Springfield, Illinois, USA).

\section{RESULTS AND DISCUSSION}

\section{Palynology, Palaeoclimate Reconstruction, Lithology and Stratigraphy of Core E1}

The $111 \mathrm{~cm}$-long core sample E1 contains laminated sediments and massive layers up to 2 $\mathrm{cm}$ thick. Almost all of the core samples were composed of thin laminated seasonal sediments with light to dark colors. Laminated layers were interrupted by massive layers in a few levels of the core.

The fault systems have been identified in detail by seismic profiles from different directions of Lake Erçek (Figure 1) (Toker et al., 2017; Toker \& Tur, 2018). According to those results, many of the normal faults, reverse faults, tectonic uplifts, erosional unconformity and subsequent erosion have been described from the seismic profiles of the bottom sediments of the lake (Toker et al., 2017; Toker \& Tur, 2018). Lake Erçek core samples have different depositional time spans because of different sampling locations, such as from the hanging-footwall of the faults or deposits with eroded upper levels (Figure 1). 


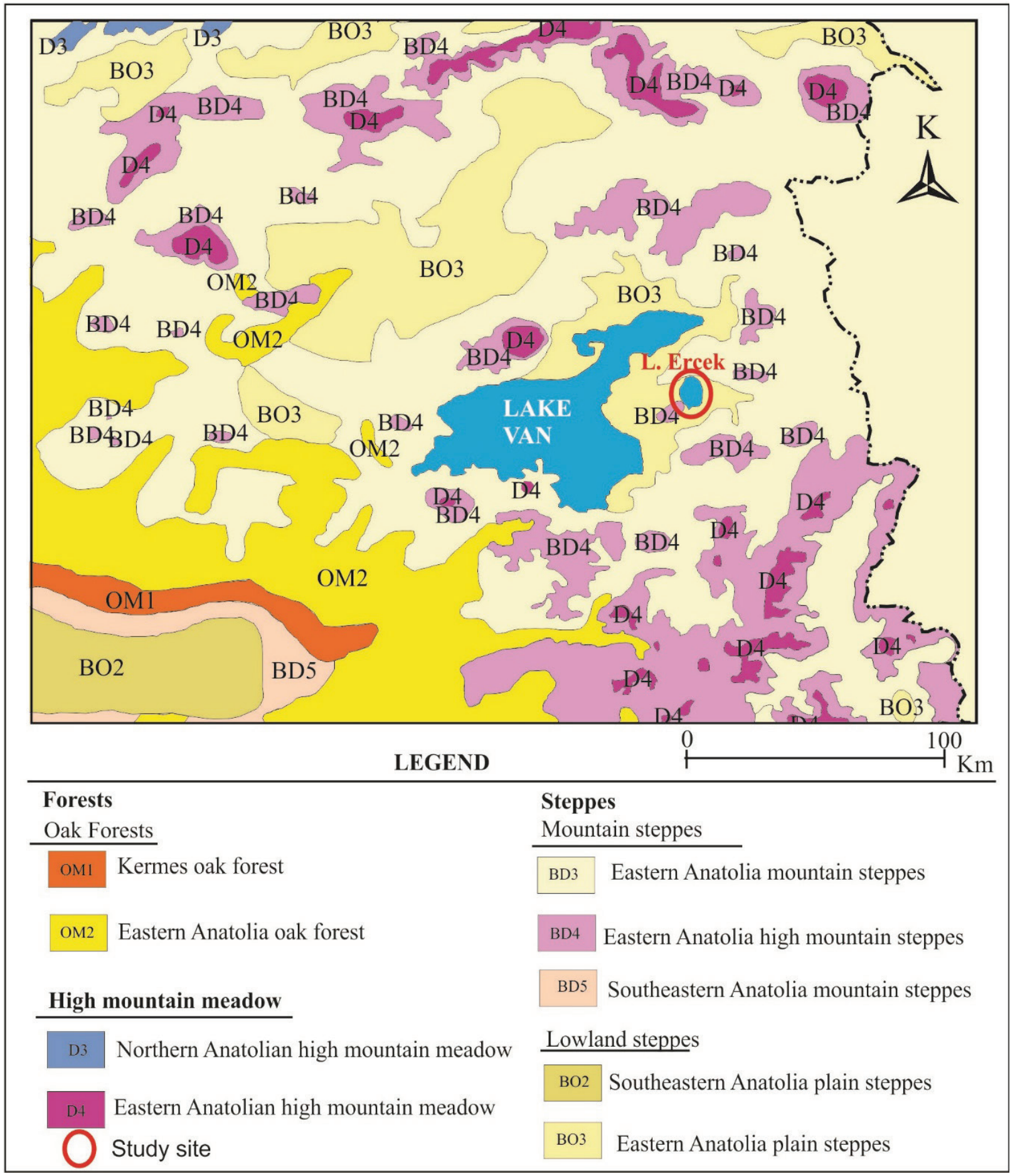

Figure 2. Vegetation map of surroundings of Lake Erçek and Eastern Anatolia (modified after Eken et al., 2006). Şekil 2. Doğu Anadolu ve Erçek Gölü çevresinin vejetasyon haritası (Eken ve diğ., 2006'dan düzenlenerek). 
The pollen diagram of the E1 short core samples has uncommon peaks of some taxa, incompatible with the Meghalayan stage. The high amount of pollen grains from semi-arid and halophytic plants such as Amaranthaceae in the samples indicates another time span of Holocene for the E1 core sample. Two scenarios can be suggested for the deposition age of E1 core; one may be a result of sampling from the footwall of the normal faulted system of the lake bottom, with missing upper levels; and the second scenario is slumping of the uppermost levels. Also, both scenarios may have been at work together. The remarkable peaks of some pollen curves in the E1 pollen diagrams are favorable for correlation with Lake Van pollen diagrams and the key points are shown with red dots on the pollen diagram of E1 (Figure 3). According to the correlations, the core sample has paraconformity in some levels (Figure 3). Younger sediments continued deposition after erosion or the downward move of the hanging wall of the fault, and hereby a paraconformity was formed between the upper and lower part of the core.

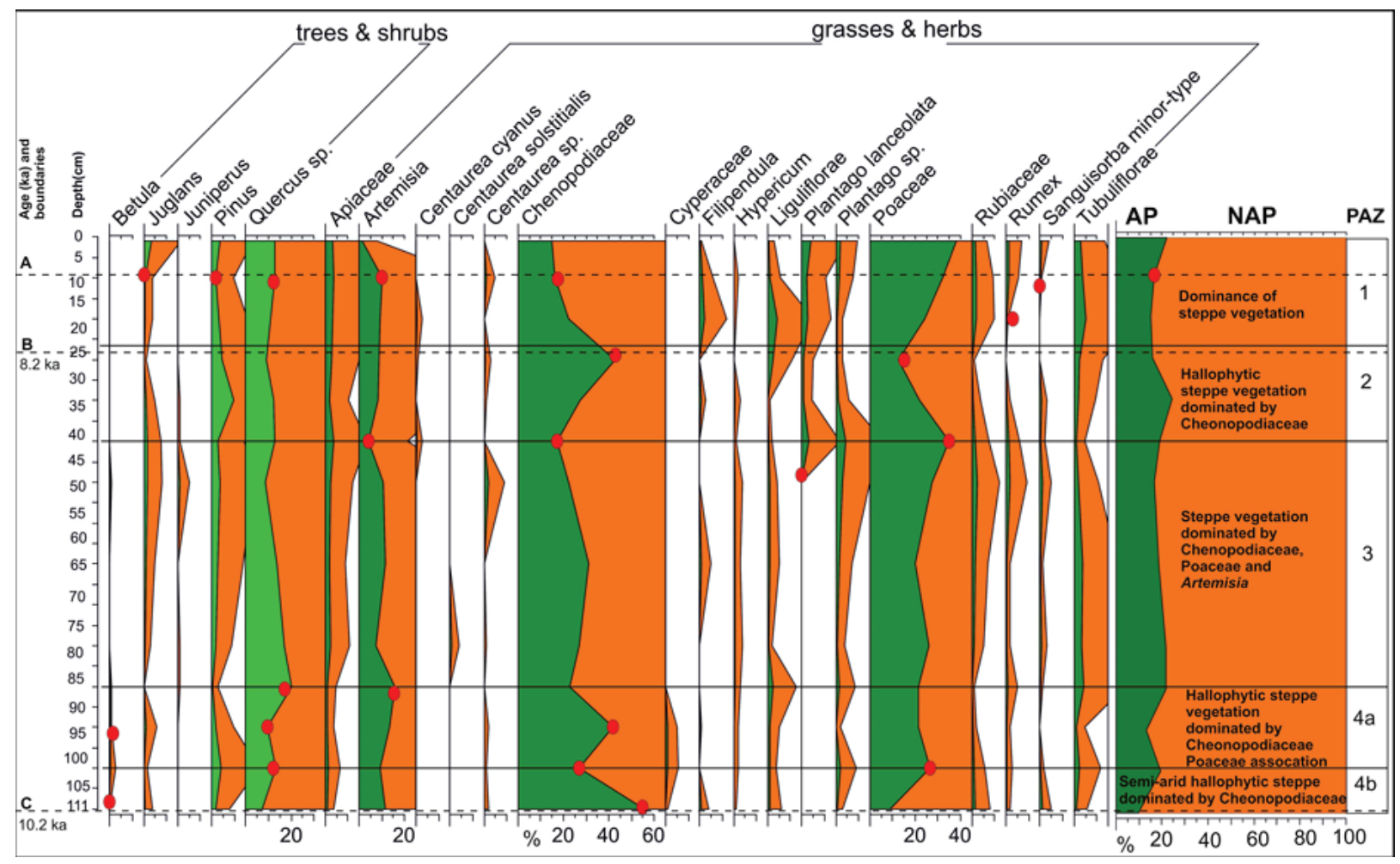

Figure 3. Simplified pollen diagram of E1 core samples (exaggeration value 5). A is the paraconformity boundary of Greenlandian and Meghalayan, B and C are tentative time scales of E1 core, PAZ is Pollen Assemblage Zone and red dots are correlation tie points with Lake Van pollen diagram samples (Wick et al., 2003; Litt et al., 2009, Kaplan, 2010).

Şekil 3. E1 karot örneklerinin sadeleştirilmiş polen diyagramı (abartı değeri 5 'dir). A; Greenlandian ve Meghalayan parakonformite sınırıdır, B ve C E1 karotunun değişebilir yaşları, PAZ; polen topluluk zonudur ve kırmızı noktalar Van Gölü polen diyagramları (Wick vd., 2003; Litt vd., 2009, Kaplan, 2010) ile yapılan karşılaştırma noktalarıdır. 
E1 core sample revealed a very rich palaeoflora, with eighty-eight taxa. Some of these rich palaeofloral elements were observed just in several samples and have limited values under $1 \%$; therefore, only pollen grains which have a continuous curve and meaningful values are shown on the pollen diagram of E1 core samples (Figure 3). According to the pollen diagram of E1, nonarboreal pollen grains (NAP) represented by Amaranthaceae, Poaceae and Artemisia are defined as the predominant and main elements of the palaeoflora (Figure 3). The pollen grains (AP) have a low ratio: deciduous Quercus are the main element of the trees and shrubs, with less than $18 \%$ value, while the second most dominant AP element Pinus curve value is less than 5\% (Figure 3). Juglans is one of the most important AP elements in Lake Van Basin as an anthropogenic indicator but has a very limited value on the uppermost part of the diagram (Figure 3).

According to the abundance of the taxa, four different pollen assemblage zones (PAZ) may be distinguished in the pollen diagram of E1 (Figure 3 ). The ratio of arboreal/nonarboreal (AP/NAP) pollen grains changes between $8 \%$ minimum in the lowest part and $25 \%$ maximum in the upper part of the diagram. Changes in the AP are mainly due to differences in the deciduous Quercus values. Amaranthaceae reach their maximum value at the bottom of the diagram with about $60 \%$ and show a minimum of $15 \%$ at the top of the diagram. Poaceae reach maximum value at the top of the diagram with about $40 \%$ and the minimum at the bottom of the diagram with about $10 \%$. Poaceae values increase, whereas Amaranthaceae values decrease. The pollen diagram has been separated into four different pollen assemblage zones (PAZ) according to distinct changes in the amount of AP and NAP pollen (Figure 3). PAZ4 is characterized by a maximum amount of Amaranthaceae and a minimum amount of Quercus and Poaceae pollen. The significant decrease of Amaranthaceae and increase in Quercus and Poaceae curves at the middle of PAZ4 suggest a short-term climate and also regional change around the study site. PAZ4 was separated into two subzones named as $4 \mathrm{a}$ and $4 \mathrm{~b}$. PAZ3 is characterized by the dominance of Amaranthaceae, Poaceae and Artemisia steppe. In the upper part of PAZ3, Amaranthaceae reach their minimum value whereas Poaceae have a peak value in the same zone. The boundary between PAZ3 and PAZ2 has been defined according to the maximum and minimum values of those taxa. The PAZ2 is represented by a distinct increase of Amaranthaceae and a decrease in Poaceae pollen grains. Dominance of halophytic steppe vegetation is characteristic for PAZ2. In PAZ1, the curve of Poaceae increases, whereas the curves of Amaranthaceae and Artemisia prominently decrease. PAZ1 is characterized by steppe vegetation.

All the taxa changes in the E1 pollen diagram indicate alternating arid (halophytic) and relatively humid phases during the deposition of core E1 sediments. The increase of halophytic indicator pollen grains such as Amaranthaceae and Artemisia and the decrease of humid pollen grains such as Quercus are in concordance with each other. When Amaranthaceae pollen grains increase on the pollen diagram, the Quercus curve decreases. Because of the overall changes in the palaeoflora, peak points of main taxa on the E1 diagram indicate palaeoclimate change rather than local palaeoflora changes.

The high amount of Amaranthaceae pollen grains (about 60\%), Poaceae, Quercus and the other curves such as Artemisia, the Compositae tubulifloreae type, Rumex, Pinus, Juniperus, Sanguisorba Minor on the pollen diagram are in accordance with the Greenlandian stage of Holocene and are comparable to the pollen data of Lake Van (Wick et al., 2003; Litt et al., 2009). A high quantity of Amaranthaceae (about $60 \%$ ) is typical for the early Holocene (Greenlandian) in the pollen diagram of Lake Van (Litt et al., 2009). According to the tentative time scale of E1 core, 
PAZ 4 and 3 of core E1 may correspond to the Greenlandian stage based on similarities with the pollen curves of Lake Erçek and Lake Van. Upwards in the E1 pollen diagram, a distinct increase of Amaranthaceae and a decrease of Poaceae and Quercus pollen grains indicate short term climate change, with a cooling event arising from the evaporative period during PAZ 2.

The semi-arid-dry phase of Lake Erçek is comparable with several areas such as Anatolia, the Near East, Cyprus, Greece, Bulgaria, Poland, etc. An abrupt arid event has been identified from the Dead Sea (Migowski et al., 2006). Results from Anatolia, Cyprus, Greece and Bulgaria provide concrete evidence for 8.2 BP cold events and central Anatolia is the best recognized of all those regions (Weninger et al., 2006). This cooling event was also reported on coastal East Asia (Park et al., 2018) and in Poland (Filoc et al., 2017). The Greenlandian stage of Holocene is characterized by halophytic semi-arid steppe vegetation in the Lake Erçek region according to the palynological and stratigraphical results and comparisons with nearby of E1 samples.

\section{Palynology, Palaeoclimate Reconstruction, Lithology and Stratigraphy of Core E10}

The core sample E10 contains thin laminated sediments from light to dark grey and light to dark brown in color, thin massive layers, normal graded layers and tephra layers (Figure 4). Lake Van basin has many volcanic centers such as Nemrut and Süphan, etc. producing tephra material (Figure 1). Tephra deposits in Lake Van basin have been investigated from Lake Van core samples and also well-exposed stratigraphic sections (Litt et al., 2009; Kaplan, 2010; Landmann et al., 2011; Sumita and Schmincke, 2013; Schmincke et al., 2014; Makaroğlu et al., 2018). Tephra layers in the Lake Van sediments mainly originate from the Nemrut and Süphan volcanoes (Landmann et al., 1996b; Landmann et al., 2011; Sumita and Schmincke, 2013; Schmincke et al., 2014). The regional variety of the thickness of the plinian fall deposits from Nemrut volcano indicate that the fallout fan extends to the east (Karaoğlu et al., 2005). Different grain-sized tephra layers (fallout deposits) extending to the east were deposited at the bottom of Lake Van in different subbasins during the Meghalayan stage. Tephra 2 of Lake Van Northern Basin (Figure 4) (Kaplan, 2010), tephra 3 of Ahlat Ridge (Figure 4) (Litt et al., 2009), tephra layer A (ash layer) of Tatvan Basin (Landmann et al., 1996b) and Tephra T1 of the Eastern Fan of Lake Van (Makaroğlu et al., 2018) correspond to each other. Varve based dating of the tephra layers of Lake Van is $2.6 \mathrm{kyr}$ (Landmann, et 1., 1996a; Landmann et al., 1996b). The Lake Erçek tephra layer is numbered T1 in this study (Figure 4). Pollen dating and tephra layer correlation between Lake Erçek, Lake Van Ahlat Ridge and Lake Van Northern Basin indicate the same tephra layer (Figure 4). The tephra layer was also sampled and investigated for pollen analysis but neither pollen nor any other palynomorphs or organisms were found.

E10 core samples are mainly dominated by NAP pollen grains with values between $67 \%$ and $83 \%$ (Figure 5). Poaceae pollen grains are dominant in the NAP with the values ranging between $20 \%$ and 38\%. Amaranthaceae, Apiaceae, Asteraceae and Artemisia pollen grains are the other dominant taxa on the pollen diagram of sample E10 (Figure 5). Other NAP elements such as Hypericum, Plantago lanceolata, Plantago sp., Rumex, Sanguisorba minor and Cyperaceae pollen grains display a continuous curve on the pollen diagram with maximum $5 \%$ values. 


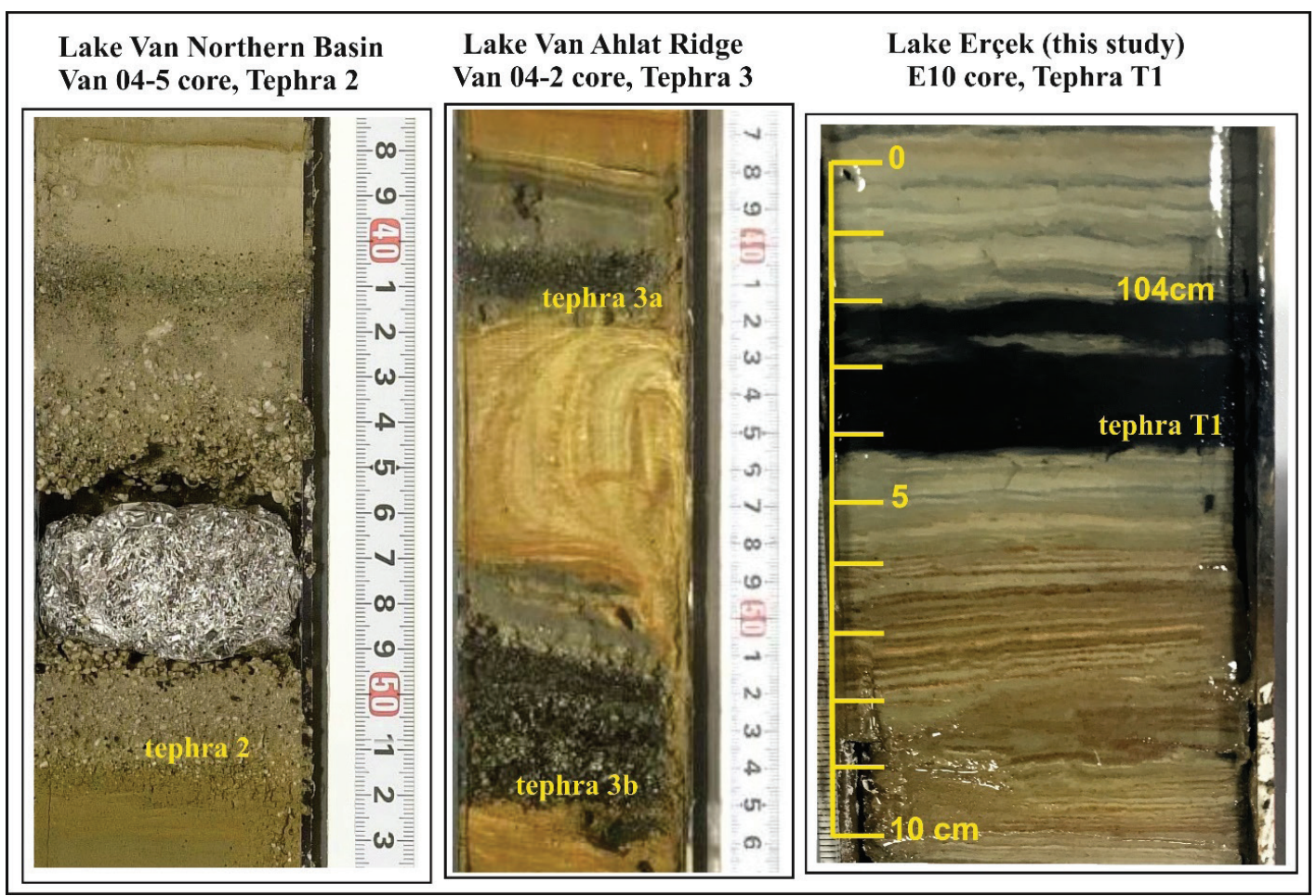

Figure 4. Tephra layers of Lake Van Northern Basin, Ahlat Ridge and Lake Erçek core E10 (tephra photos of Northern Basin and Ahlat Ridge modified from Kaplan, 2010).

Şekil 4. Van Gölü Kuzey Havzast, Ahlat Sirtı ve Erçek E10 karotunun tefra seviyeleri (Kuzey Havzası ve Ahlat Sirtı'nın tefra fotoğrafları Kaplan, 2010'dan değiştirilerek alınmıştır).

The maximum AP pollen grain value is $27 \%$ and most of the value is represented by Quercus pollen grains, at 25\% (Figure 5). The second dominant taxon of AP is Pinus with a maximum value of 5\%. Juglans, Juniperus and Betula pollen grains are the other main AP elements with uncontinuous curves of less than 3\% (Figure 5).

The core sample E10 on the pollen diagram was separated into two pollen assemblage zones (PAZ) according to the distinct increase and decrease of Poaceae, Quercus, and Amaranthaceae and the onset of continuous Juglans pollen curves (Figure 5). The tentative time scale of E10 is mainly based on pollen correlations (correlation points are shown with red dots on Figure 5 and 6) of the main palaeofloral elements of AP and NAP between this study and Lake Van pollen diagrams (Wick et al., 2003; Litt et al., 2009; Kaplan, 2010; Kaplan and Örçen, 2011). Onset of the continuous
Juglans curve has been dated to about 2-2.1 ka BP in the Lake Van sediments (Wick et al., 2003; Litt et al., 2009; Kaplan, 2010; Kaplan \& Örçen, 2011). The continuous Juglans curve corresponds to a depth of about $65 \mathrm{~cm}$ in the E10 core (Figure 5). That level also indicates increasing human impact in the Lake Van Basin (Wick et al., 2003; Kaplan \& Örçen, 2011).

PAZ2 (between 110-145 cm depth) at the bottom side of the pollen diagram is characterized by the dominance of NAP pollen grains with about $80 \%$ value (Figure 5) and has also been separated into two subzones, $2 \mathrm{a}$ and $2 \mathrm{~b}$, according to the increase of Amaranthaceae and decrease of Poaceae, Quercus and Cyperaceae pollen grains. Subzone $3 b$ is represented by relatively more halophytic, semi-arid conditions than subzone $3 \mathrm{a}$ (Figure 5). The uppermost level of PAZ3 is dated to about 2.6 ka years, based on the tephra layer. 


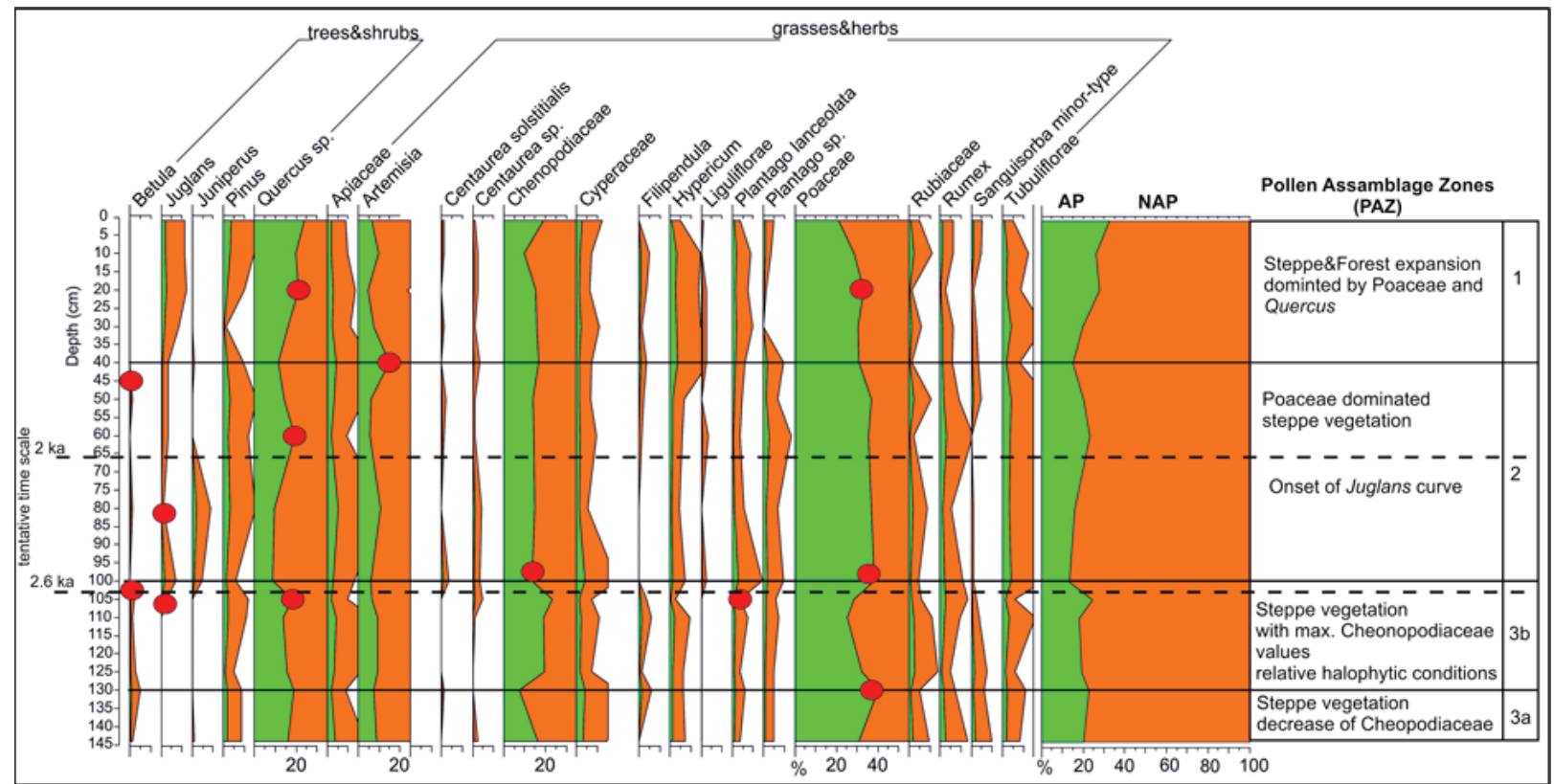

Figure 5. Simplified pollen diagram of E10 core samples (red dots shows tie points for tentative dating, exaggeration value is 5 ).

Şekil 5. E10 karot örneklerinin sadeleştirilmiş polen diyagramı (kırmızı noktalar değişebilir yaş için bağlantı noktalarıdır ve abartı değeri 5 'dir).

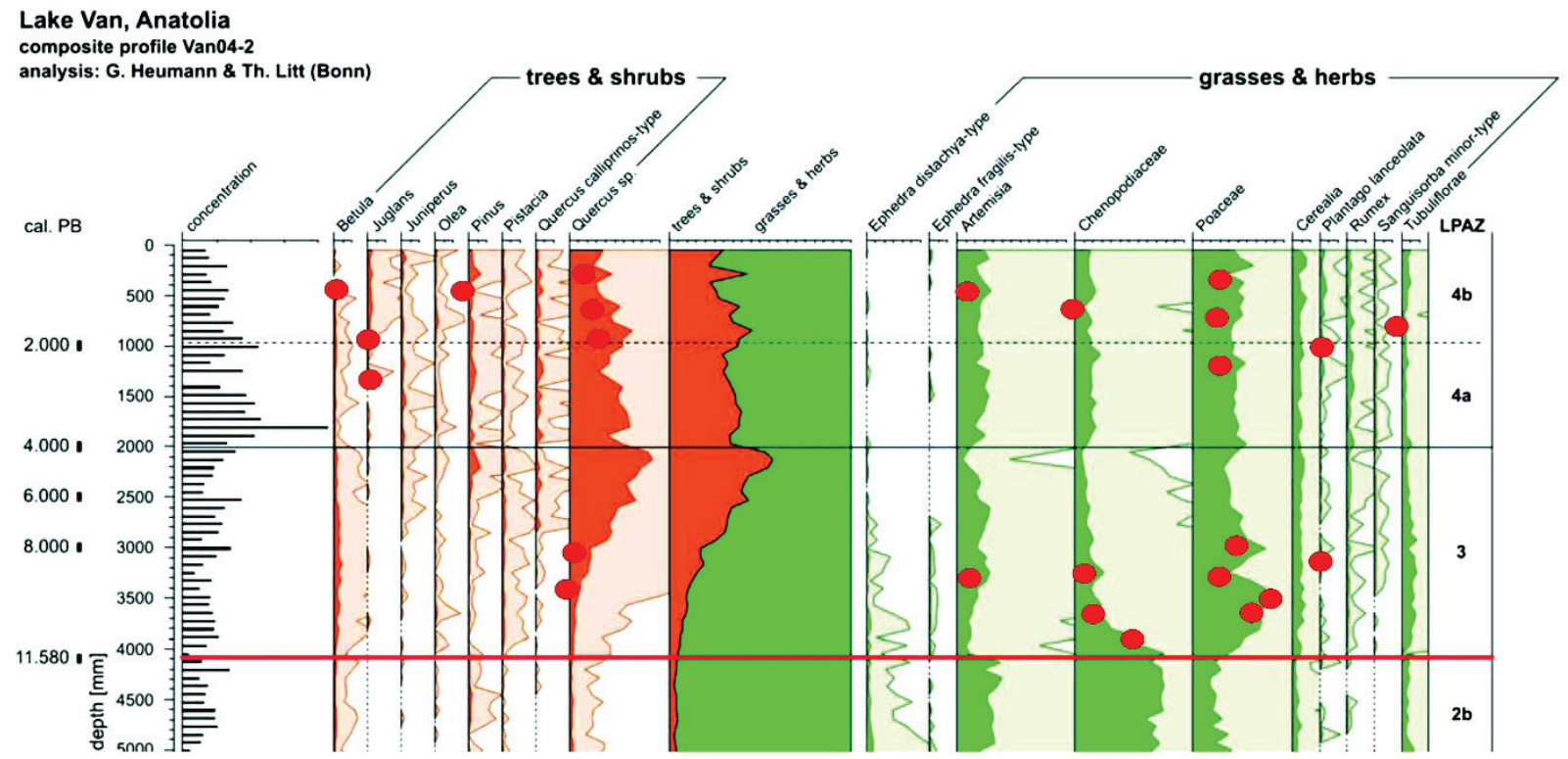

Figure 6. Pollen correlation tie points (red dots) between Lake Van pollen diagram (Litt et al., 2009) and this study. Şekil 6. Van Gölü polen diyagramı (Litt ve diğ., 2009) ve bu çalışma arasında yapılan polen korelasyonu noktaları (kırmızı noktalar). 
PAZ1 (between 110-0 cm depth) is characterized by a dominance of NAP pollen grains such as Poaceae, Amaranthaceae and Artemisia (Figure 5). The boundary of the PAZ1 and PAZ2 zones is mainly separated by the onset of the continuous Juglans curve. Juglans regia is a very important anthropogenic plant in the Lake Van Basin around Ahlat and Adilcevaz (Bitlis) regions in the present day and Juglans has commonly been cultivated in Lake Van Basin prevalently and economically from past to present (Muradoğlu \& Balta, 2010). Juglans is also reported as an anthropogenic indicator at Lake Urmia (Talebi et al., 2016) in the Caspian Sea region from 2300 BP to present (Ramezani et al., 2016) and the semi-continuous curve of Juglans pollen grains for Lake Almalou was dated to cal $1500 \mathrm{BP}$ as a fruticultural indicator (Djamali et al., 2009). Rumex and Plantago lanceolata have also been identified as anthropogenic indicators. In contrast to Europe, cereal type pollen grains have a limited importance in the Near East because of their natural occurrence and also cultivation (Behre, 1981). Both Rumex and P. lanceolata have a continuous curve on the pollen diagram of the E10 core of less than 5\% and without showing any significant increase (Figure 5).

PAZ1b (between 40-0 cm depth) is characterized by steppe elements such as Amaranthaceae, Poaceae and Artemisia but in this zone Poaceae and Artemisia curves decrease while Amaranthaceae increase (Figure 5). The main AP elements Quercus, Juglans and Pinus pollen grains also increase in this zone and reach their maximum values (Figure 5). From the lower to the upper part of the zone, AP pollen grains increase by about $15 \%$ (Figure 5).

\section{GENIŞLETILMIŞ ÖZET}

Bu çalı̧̧mada, Erçek Gölü'nden alınmış olan E1 ve E10 karot örneklerinin palinolojik, litolojik ve stratigrafik ilk inceleme sonuçları sunulmuştur. Karot örnekleri litolojik olarak çoğunlukla ritmik laminalı çökel içermektedir, bunun yanı sıra masif tabakall seviyeler ile E10 karotunda tanımlanan bir tefra seviyesi içermektedir. Göl tabanının faylı yapısı (sismik araştırma sonuçları ve detaylar için bakınız Toker vd., 2017; Toker ve Tur, 2018) nedeniyle her iki karot, farkl y yaş aralıklarını göstermektedir. E1 sediment karotunun polen analizi sonuçlarının, Van Gölü Geç Holosen (Meghaliyen) polen diyagramlart ile uyumsuzluğu, gözlenen Amaranthaceae polenlerinin \%60 civarındaki bolluğu ile yaprak döken Quercus ve Poaceae polenlerinin tüm diyagramdaki minimum değeri ile Toker vd., 2017 ve Toker ve Tur, 2018 tarafindan tanımlanan, göl tabanındaki normal faylarm lokasyonu ve karot lokasyonu karşılaştırıldiğında, E1 karotunun Grönlandiyen yaş aralığına denk geldiği düşünülmektedir. Taban bloğundan örnekleme sonucu, E1 karotunun üst seviyeleri çökel içerisinde gözlenmemiştir. Bu normal fay oluşumu ve taban bloğunun bu çalışma kapsamında örneklenmiş oluşu nedeniyle, E1 ve E10 sediment karotları farkl yaş aralıklarını temsil etmektedir. Değişebilir yaş seviyeleri için, Van Gölü çökellerinden elde edilen polen diyagramlar ve tefra seviyeleri ile korelasyonlar yapılmuştır. Korelasyon yapılan seviyeler için Amaranthaceae, Artemisia, Poaceae, Quercus, Juglans, Compositae tubulifloreae-type, Plantago lanceolata, Betula gibi tüm örneklerde en bol gözlenen polen taksonlarinin belirgin değişim gösterdiği seviyeler baz alınmıştır ve bu seviyelerden bazılart diyagramlar üzerinde gösterilmiştir (Şekil 4 ve 5). Bu korelasyonlar sonucunda E10 karotunun ise, Meghaliyen döneminde çökelmiş olduğu belirlenmiştir. E10 değişebilir zaman ölçeği, devamlı Juglans eğrisinin görülmesine, karot içinde tanımlanan tefra seviyesine, Amaranthaceae, Poaceae ve Quercus gibi paleovejetasyonun ana elementlerinin bolluk değerlerine ve bu bulguların Yakın çevredeki Holosen polen diyagramları ile karşılaştırılmasına göre yapılmıştır.

Erçek Gölü bölgesinde Holosen boyunca, paleoflora değişimleri ve paleovejetasyon gelişimi kısa dönemli iklimsel değişimler, lokal flora değişimleri ve insan etkisi kontrolü altında 
şekillenmiştir. Polen diyagramlarındaki Juglans, Plantago lanceolota, Rumex polenlerinin varlığl, yetiştiricilik ve otlatmaya da işaret etmektedir. Halofitik Amaranthaceae bitkisinin polenlerindeki artış ve Cyperaceae gibi sucul bitki polenlerinin azalışı, Meghaliyen ve Grönlandiyen boyunca kısa dönemli kurak koşulların hakimiyetine işaret etmektedir. Greenlandian dönemini temsil eden maksimum Amaranthaceaepolen değeri, yarı kurak iklim koşullarını göstermektedir ve bu Holosen başlangıcından sonra gözlenen küresel iklim salınımları ile uyumludur. E1 sediment karotunun polen verilerine göre yüksek orandaki kuraklı belirteci bu bitki polenlerinin varlı̆̆ küresel 8,2 bin yıl soğuma olayı ile karşılaştırılabilir olarak görünmektedir. Diğer yandan, Meghaliyen katı Erçek Gölü bölgesi için Holosen başlangıcına göre minimum Amaranhaceae, Artemisia ve maksimum Quercus değeri ile daha nemli iklim özelliklerine sahip olarak tanımlanmıştır.

\section{ACKNOWLEDGMENT}

This study was funded by Scientific Research Projects Unit of Van Yüzüncü Y1l University (Project Number: MiM-B-075). I would like to thank my undergraduate students for their help during field studies.

\section{ORCID}

Güldem Kamar (D) https://orcid.org/0000-0003-4712-5997

\section{REFERENCES / KAYNAKLAR}

Alan, H., Bozkurt, E., Çaglan, D., Dirik, K., Özkaymak, Ç., Sözbilir, H. ve Topal, T. (2011). Report of Van Earthquakes (Tabanl1-Edremit). TMMOB Society of Geological Engineering, Publication, 110, Ankara.

Beug, H.J. (2004). Leitfaden der Pollenbestimmung. Verlag dr. Friedrich Pfeil (München) Germany.

Behre, K.E. (1981). The interpretation of anthropogenic indicators in pollen diagrams. Pollen et Spores, $23,235-247$.

Biltekin, D., Eriş, K. K., Çağatay, M. N., Akçer-Ön, S. \& Akkoca, D. B. (2018). Late Pleistocene-
Holocene environmental change in eastern Turkey: a multiproxy palaeoecological data of vegetation and lake-catchment changes. Journal of Quaternary Science, 33(5) 575-585. https://doi. org/10.1002/jqs.3037

Çağatay, M. N., Öğretmen, N., Damcı, E., Stockhecke, M., Sancar, Ü., Eriş, K. K. \& Özeren, S. (2014). Lake level and climate records of the last $90 \mathrm{ka}$ from the Northern Basin of Lake Van, eastern Turkey. Quaternary Science Reviews, 104, 97-116. https://doi.org/10.1016/j.quascirev.2014.09.027

Dean, J. R., Jones M. D., Leng, M. J., Stephen R. Noble, S. R., Metcalfe, S. E., Sloane, H. J., Sahy, D., Eastwood, W. J. \& Roberts, C. N. (2015). Eastern Mediterranean hydroclimate over the late glacial and Holocene, reconstructed from the sediments of Nar Lake, central Turkey, using stable isotopes and carbonate mineralogy. Quaternary International, 124, 162-174.

Djamali, M., de Beaulieu, J-L., Andrieu-Ponel, V., Berberian, M., Miller, NF., Gandouin, E., Lahijani, H., Shah-Hosseini, M., Ponel, P., Salimian, M. \& Guiter, F. (2009). A late Holocene pollen record from Lake Almalou in NW Iran: evidence for changing land-use in relation to some historical events during the last 3700 years. Journal Archaeological Science, 36, 1364-1375.

Ediger, V. S. (1986). Sieving techniques in palynological sample processing with special reference to the MRA system. Micropaleontology, 32(3), 256-270.

Eken, G., Bozdoğan, M., İsfendiyaroğlu, S., Kılıç, D.T. \& Lise, Y. (editörler) (2006). Türkiye'nin Önemli Doğa Alanları. Doğa Derneği.

Erdtman, G. (1943). An Introduction to Pollen Analysis. Chronica Botanica, New York.

Eriş, K. K. (2013). Late Pleistocene Holocene sedimentary records of climate and lake-level changes in Lake Hazar, Eastern Anatolia, Turkey. Quaternay International, 302, 123-134.

Faegri, K. \& Iversen, J. (1989). Textbook of Pollen Analysis, fourth ed. Wiley, New York.

Fiłoc M, Kupryjanowicz M, Szeroczyńska K, Suchora, \& Rzodkiewicz, M. (2017). Environmental changes related to the $8.2 \mathrm{ka}$ event and other climate fluctuations during the Middle Holocene: evidence from two dystrophic lakes in NE Poland. The Holocene, 27, 1550-1566. https://doi. org/10.1177/0959683617702233

Hayrapetyan, N., Hakobyan, E., Kvavadze, E., Gabrielyan, I., Brunch A. A. (2018). Late Holocene environmental changes in the Lake Sevan basin- 
implications from palynological and carpological analyses of peatbog sediments from Tsovinar-1, Armenia. PRIDE-RCMNS conference Ecosystem isolation and connection: rise and demise of biota in the Pontocaspian-Caucasian region (48).

İpek, S. \& Sarı, M. (1998). Erçek Gölü’nün Batimetrik Özelliklerinin Belirlenmesi (Determination of the bathymetric features of Lake Erçek), (YDABÇAG-609-A). Project of Scientific and Technical Research Council of Turkey.

Kamar, G. (2018). Palynology of Lake Arin (Eastern Anatolia, Turkey) deposits and its relation with water level change of Lake Van: Preliminary findings. Quaternary International, 486, 83-88.

Kaplan, G. (2010). Van Gölü Kuzey Havzası'nın Geç Holosen Palinolojisi [Yayımlanmamış Doktora tezi]. Yüzüncü Yıl University.

Kaplan, G., Örçen, S. (2011). Late Holocene Paleoflora of Lake Van Northern Basin. Bulletin of the Earth Sciences Application and Research Centre of Hacettepe University, 32(2) 139-150.

Kaplan, G. (2013a). Palynological analysis of the Late Pleistocene terrace deposits of Lake Van, eastern Turkey: Reconstruction of paleovegetation and paleoclimate. Quaternary International, 292, 168175.

Kaplan, G. (2013b). Van Gölü Geç Holosen Polenleri. Yerbilimleri (Bulletin of Turkish Earth Sciences), 34(1), 37-52.

Karaoğlu, Ö., Özdemir, Y., Tolluoğlu, A.Ü., Karabıyıkoğlu, M., Köse, O. \& Froger, J. L. (2005). Stratigraphy of the volcanic products around Nemrut Caldera: implications for reconstruction of the caldera formation. Turkish Journal of Earth Science, 14,123-143.

Kılıç, N. K., Caner, H., Erginal, A. E., Ersin, S., Selim, H, H. \& Kaya, H. (2018). Environmental changes based on multi-proxy analysis of core sediments in Lake Aktaş, Turkey: Preliminary results. Quaternary International, 486, 89-97.

Koçyiğit, A., Yılmaz, A., Adamia, S. \& Kuloshvili, S. (2001). Neotectonics of east Anatolian plateau (Turkey) and lesser Caucasus: implication for transition from thrusting to strike-slip faulting. Geodinamica Acta, 14(1-3), 177-195.

Landmann, G., Reimer, A., Lemcke, G. \& Kempe, S. (1996a). Dating Late Glacial abrupt climate changes in the 14, 570 years long continuous varve record of Lake Van/ Turkey. Palaeogeography Palaeoclimatology Palaeoecology, 2, 107-118.

Landmann, G., Reimer, A. \& Kempe, S. (1996b). Climatic induced lake level changes of Lake
Van/Turkey during the transition Pleistocene/ Holocene. Global Biogeochemical Cycles, 10(4), 797-808.

Landmann, G., Steinhauser, G., Sterba, J.H, Kempe, S. \& Bichler, M. (2011). Geochemical fingerprints by activation analysis of tephra layers in Lake Van sediments, Turkey. Applied Radiation Isotopes, 69, 929-935.

Litt, T., Krastel, S., Sturm, M., Kipfer, R., Örcen, S., Heumann, G., Franz, S. O., Ülgen, U. B. \& Niessen, F. (2009). 'PALEOVAN', International Continental Scientific Drilling Program (ICDP): site survey results and perspectives. Quaternary Science Reviews, 28, 1555-1567.

Litt, T., Pickarski, N. \& Heumann, G. (2014). A 600,000 Year Long Continental Pollen Record from Lake Van, Eastern Anatolia (Turkey). Quaternary Science Reviews, 104, 30-41.

Makaroğlu, Ö., Çağatay, M. N., Nowaczyk, N. R., Pesonen, L. J. \& Orbay, N. (2018). Discrimination of Holocene tephra units in Lake Van using mineral magnetic analysis. Quaternary International, 486, 44-56.

Mayewski, P.A.; Rohling, E.E.; Stager, J.C., ..., Steig, E. J. (2004). Holocene climate variability. Quaternary Research, 62(3), 243-255. https://doi. org/10.1016/j.yqres.2004.07.001

Migowski, C., Stein, M., Prasad, S., Negendank, J. \& Agnon, A. (2006) Holocene climate variability and cultural evolution in the Near East from the Dead Sea sedimentary record. Quaternary Research, $66,421-431$.

Moore, P. D. \& Webb, J. A. \& Collinson, M. E. (1991). Pollen Analysis, second edition. Blackwell, Oxford UK.

Muradoğlu, F. ve Balta, F. (2010). Ahlat (Bitlis) Yöresinden Selekte Edilen Cevizlerin (Juglans regia L) Bazı Fiziksel ve Kimyasal Özellikleri. YYÜ Journal of Agricultural Science, 20(1), 4145.

Ocakoğlu, F., Kır, O., Yılmaz, İ. Ö., Açıkalın, S., Erayık, C., Tunoğlu, C. \& Suzanne Leroy, S.A.G. (2013). Early to Mid-Holocene Lake level and temperature records from the terraces of Lake Sünnet in NW Turkey. Quaternay International, 369, 175-184.

Okuldaş, C. ve Üner, S. (2013). Alaköy Fayı'nın Jeomorfolojik Özellikleri ve Tektonik Etkinliği (Van Gölü Havzası - Doğu Anadolu). Bulletin of the Earth Sciences Application and Research Centre of Hacettepe University, 34(3), 161-176. 
Ön, Z. B., \& Özeren, M. S. (2019). Temperature and precipitation variability in eastern Anatolia: Results from independent component analysis of Lake Van sediment data spanning the last $250 \mathrm{kyr}$ BP. Quaternary International, 514(2019) 119129.

Ön, Z., Özeren, M., Akçer Ön, S. \& Çağatay, M. (2017) Spectral Features of 250 kyr Long Lake Van Sediments: Milankovitch Cycles and Their Harmonics. Geological Bulletin of Turkey, 60(4) 471-488. https://doi.org/10.25288/tjb.360604

Park, J., Park, J., Yi, S., Kim, J. C., Lee, E. \& Jin, Q. (2018). The $8.2 \mathrm{ka}$ cooling event in coastal East Asia: High-resolution polen evidence from southwestern Korea. Scientific Reports, 8, 12423.

Pickarski, N., Kwiecien, O., Djamali, M. \& Litt, T. (2015). Vegetation and environmental changes during the last interglacial in eastern Anatolia (Turkey): a new high-resolution polen record from Lake Van. Palaeogeography Palaeoclimatology Palaeoecology. 435, 145-158.

Ramezani, E., Mrotzek, A., Mohadjer, M. R. M., Kakroodi, A.A., Kroonenberg, B. S. \& Joosten, H. (2016). Between the mountains and the sea: Late Holocene Caspian Sea level fluctuations and vegetation history of the lowland forests of northern Iran. Quaternary International, 408, 5264.

Sağlam Selçuk. A. (2016). Evaluation of the relative tectonic activity in the eastern Lake Van basin, East Turkey. Geomorphology, 270, 9-21.

Schmincke, H.U. \& Sumita, M. \& Paleovan scientific team (2014). Impact of volcanism on the evolution of Lake Van (eastern Anatolia) III: periodic (Nemrut) vs. episodic (Süphan) explosive eruptions and climate forcing reflected in a tephra gap between ca. $14 \mathrm{ka}$ and ca. $30 \mathrm{ka}$. Journal of Volcanology and Geothermal Research, 285, 195213.

Sumita, M. \& Schmincke, H.-U. (2013). Impact of volcanism on the evolution of Lake Van II: temporal evolution of explosive volcanism of Nemrut Volcano (eastern Anatolia) during the past ca. 0.4 Ma. Journal of Volcanology and Geothermal Research, 253, 15-34.

Şaroğlu, F. ve Y1lmaz, Y. (1986). Doğu Anadolu'da neotektonik dönemdeki jeolojik evrim ve havza modelleri. Bulletin of the Mineral Research and Exploration, 107, 73-94.

Şengör, A.M.C. \& Yılmaz, Y. (1981). Tethyan evolution of Turkey: a plate tectonic approach. Tectonophysics, 75,181-190 (193-199, 203-241).

Şensoy, S., Demircan, M., Ulupınar, Y. (2021). Climate of Turkey. Turkish State Meteorological
Service. http://www.emcc.mgm.gov.tr/files/ climateofturkey.pdf

Talebi, T., Ramezani, E., Djamali, M., Lahijani H. A. K., Naqinezhad, A., Alizadeh, K. \& AndrieuPonel, V. (2016). The Late-Holocene climate change, vegetation dynamics, lake-level changes and anthropogenic impacts in the Lake Urmia region, NW Iran. Quaternary International, 408, 40-51.

Tatl1, A., 2004. Türkiye Vejetasyonu (Vegetation of Turkey) 2. Baskl. Bizim Büro Basımevi Kütahya, $142 \mathrm{~s}$.

Toker, M., Pınar, A. \& Tur, H. (2017). Source mechanisms and faulting analysis of the aftershocks in the Lake Erçek area (Eastern Anatolia, Turkey) during the 2011 Van event (Mw 7.1): implications for the regional stress field and ongoing deformation processes. Journal of Asian Earth Science, 150, 73-86.

Toker, M. \& Tur, H. (2018). Structural patterns of the Lake Erçek Basin, Eastern Anatolia (Turkey): evidence from single-channel seismic interpretation. Marine Geophysical Research, 39, 567-588.

Ülgen, U. B., Franz, S. O., Biltekin, D., Cagatay, M. N., Roeser, P. A., Doner, L. \& Thein, J., (2012). Climatic and environmental evolution of Lake İznik (NW Turkey) over the last similar to 4700 years. Quaternary International, 274, 88-101.

Weninger, B., Alram-Stern, E., Bauer, E., Clare, L., Danzeglocke, U., Jöris, O., Kubatzki, C., Rollefson, G., Todorova, H. \& van Andel, T. (2006). Climate forcing due to the $8200 \mathrm{cal} \mathrm{yr}$ BP event observed at Early Neolithic sites in the eastern Mediterranean. Quaternary Research, 66, 401-420.

Wick, L., Lemcke, G. \& Sturm, M. (2003). Evidence of Lateglacial and Holocene climatic change and human impact in eastern Anatolia: high resolution pollen, charcoal, isotopic and geochemical records from the laminated sediments of Lake Van. The Holocene, 13, 665-675.

Wodehouse, R. P. (1935.) Pollen. Their Structure, Identification and Significance in Science and Medicine. McGraw-Hill Book Company, New York and London.

van Zeist, W. \& Woldring, H. (1978). A polen Profil From Lake Van: A Preliminary Report. In E.T. Degens \& F. Kurtman (Eds.), The Geology of Lake Van, (pp. 115-123). MTA Enstitüsü Yayınları no: 169.

Yılmaz, Y., Şaroğlu, F. \& Güner, Y. (1987). Initiation of the neomagmatism in East Anatolia. Tectonophysics, 134, 177-199. 